\title{
A SURVEY OF ANTIBIOTICS PURCHASED WITHOUT PRESCRIPTION AMONG NON-HEALTH SCIENCE STUDENTS IN JEMBER, INDONESIA
}

\section{SURVEI PEMBELIAN ANTIBIOTIKA TANPA RESEP DI KALANGAN MAHASISWA NON-KESEHATAN DI JEMBER, INDONESIA}

\author{
Antonius Nugraha Widhi Pratama ${ }^{\left.1^{*}\right)}$, Anis Rohmawati ${ }^{2}$, Ema Rachmawati ${ }^{1}$ \\ ${ }^{1}$ Faculty of Pharmacyi Universitas Jember, Jl. Kalimantan I No. 2, Jember, East Java, Indonesia \\ ${ }^{2}$ Students of Faculty of Pharmacy, Universitas Jember, Jl. Kalimantan I No. 2, Jember, East Java, \\ Indonesia
}

Received March 5, 2018; Accepted April 29, 2018

\begin{abstract}
Previous research showed that self-medication practice with antibiotics is widespread in developing countries and tertiary students are among these consumers. This study aimed to estimate the prevalence of the use of antibiotics without prescription among non-health science students in Jember and to identify the sources of non-prescription antibiotics. This cross-sectional survey was conducted between April and June 2016 in all non-health science faculties of Universitas Jember. A questionnaire containing four main short questions about antibiotics use and questions related to socio-demographic information was distributed to students who gave consent. A number of 130 (58.5\%) respondents admitted to ever acquire antibiotics without the presence of a physician prescription. Self-medication with antibiotics tended to be done by students from rural areas $(p=0.04)$ and without health insurance $(p=0.04)$. The sources of nonprescription antibiotics vary, but pharmacy was the most frequently cited to be the source $(n=82$; 46.3\%). This study showed that the use of antibiotics without prescription among non-health science students and the sale of antibiotics without prescription among pharmacies in Jember are prevalent. Real responses from the government, relevant health professional associations, and education institutions to intervene these problems are significantly needed.
\end{abstract}

Keywords: antibiotics, Jember, non-health science students, self-medication

\begin{abstract}
ABSTRAK
Beberapa penelitian menunjukkan bahwa praktik swamedikasi dengan antibiotik marak di kalangan masyarakat negara berkembang dan mahasiswa termasuk juga sebagai konsumen antibiotika dengan cara ini. Penelitian sederhana ini bertujuan untuk mengetahui prevalensi penggunaan antibiotika tanpa resep di antara mahasiswa non kesehatan di Jember dan untuk mengetahui sumber perolehan antibiotika tanpa resep. Survei potong lintang ini dilaksanakan antara April hingga Juni 2016 di semua fakultas non-kesehatan Universitas Jember. Kuesioner yang berisi empat pertanyaan utama tentang penggunaan antibiotika dan pertanyaan terkait informasi sosio-demografi dibagikan kepada mahasiswa yang memberikan consent. Sebanyak 130 (58,5\%) responden mengaku pernah mendapatkan antibiotika tanpa resep dokter. Praktek swamedikasi dengan antibiotika cenderung dilakukan oleh mahasiswa yang berasal dari daerah rural $(p=0,04)$ dan yang tidak memiliki asuransi $(p=0,04)$. Responden mendapatkan antibiotik tanpa resep dari berbagai sumber dan apotek menjadi tempat paling sering disebutkan untuk membeli antibiotika tanpa resep $(n=82 ; 46,3 \%)$. Penelitian ini menunjukkan penggunaan antibiotika tanpa resep masih tinggi di kalangan mahasiswa non kesehatan dan penjualan antibiotika tanpa resep di apotek di Jember cenderung tinggi. Peran nyata pemerintah, organisasi
\end{abstract}

*Corresponding author: Antonius N.W. Pratama

Email: anton.farmasi@unej.ac.id 
profesi kesehatan terkait, dan institusi pendidikan untuk melakukan intervensi untuk mengatasi hal tersebut sangat diperlukan.

Kata kunci: antibiotika, Jember, mahasiswa non kesehatan, swamedikasi

\section{INTRODUCTION}

The self-medication behavior, which is a part of self-care, is commonly practiced by the people of all ages (Bertoldi et al., 2014; Donkor et al., 2012; Du and Knopf, 2009; Hassali et al., 2011; Jerez-Roig et al., 2014) living in developed countries (Aoyama et al., 2012; Guinovart et al., 2015) and in developing countries (Bertoldi et al., 2014; Eticha and Mesfin, 2014), in the city (Selvaraj et al., 2014) and villages (Skliros et al., 2010) with "modern" medicine (Mehuys et al., 2014) and traditional medicine (Clement, 2009). Health complaints that are treated by selfmedication vary from mild ones, such as headaches and fever (Eticha and Mesfin, 2014), to severe, such as depression (Khanra and Sen, 2016).

Self-medication involves the process of self-diagnosis that requires experience and sufficient knowledge. Therefore, one of the risks that can arise is misdiagnosis (Ruiz, 2010). Other problems such as medicine interactions may also happen. Self-medication action is said to be responsible if the medicine taken are the ones which do not need prescription from a doctor. Those medicine include the free or over-the-counter (OTC) medicine, Pharmacy-Prescribed-Medicine (OWA), and traditional medicine. However, considerable evidence from previous studies has shown that prescription only medicine is also used in self-medication, one of which is antibiotics (Donkor et al., 2012; Guinovart et al., 2015; Skliros et al., 2010). The purchase of antibiotics without prescription may exacerbate the control of antimicrobial resistance rates. This is a serious global threat. Although the contribution of the pattern of antibiotics purchased without prescription to the antimicrobial resistance is not very clear, but this phenomenon is thought to play an important role (Morgan et al., 2011).
Antimicrobial resistance is one of the most important health issues known to those with a background in health, including health students. This knowledge is thought to be able to make health students more alert to selfmedication using antibiotics without a prescription. However, some previous studies have shown inconsistent results (Donkor et al., 2012; Olayemi et al., 2010). A study in Ghana shows that the prevalence of self-medication using antibiotics in health students is relatively lower than in non-health students (Donkor et al., 2012), whereas a study in Nigeria shows otherwise (Olayemi, 2010). A study in Karachi shows a high prevalence of selfmedication using antibiotics among students (Shah et al., 2014). Some studies of selfmedication conducted on health students, particularly on the pharmacy students, have shown quite interesting results, because although the students have good knowledge, but in practice they have not demonstrated a wise use of antibiotics (Dhingra et al., 2015; Fejza et al., 2016). In the study, researchers suggested to conduct intervention or training activities to increase the use of antibiotics wisely among students. Based on the results of the study, a self-medication study on the use of antibiotics among non-health students becomes an interesting topic. Since the practice of irresponsible use of antibiotics occur in health students, it can be assumed that the non-health students also have a great risk of doing the same practice. This study was conducted to find out the prevalence of selfmedication using antibiotics in non-health students and to figure out the places where antibiotics can be purchased without a prescription.

\section{METHODS}

This study was conducted using a paperbased interview and face-to-face interview in 
April-June 2016. The respondents were selected using a convenient sampling technique. Respondents were taken from ten non-health faculties of Universitas Jember, namely Faculty of Law, Faculty of Social and Political Sciences, Faculty of Agriculture, Faculty of Economics, Faculty of Teachers Training and Education, Faculty of Letters, Faculty of Agricultural Technology, Faculty of Mathematics and Natural Sciences, Faculty of Engineering, and Faculty of Information System. The inclusion criteria included undergraduate (S-1) students who were active from batch 2012-2015 and who were willing to sign the informed consent sheet. Respondents were excluded if they had a history of chronic disease requiring regular therapy or if they did not answer the questionnaire completely. Research permit was obtained from Vice Rector I of Universitas Jember (No. 4937/UN25/LT/ 2016). The identity of each respondent was kept confidential and the data were only accessible to the researchers.

The questionnaire consisted of two parts. Part A covered the demographic data of the respondents including gender, residence, pocket money, place of origin, and type of insurance. Part B covered four questions related to self-medication using antibiotics. The first question was about whether the respondents consumed or used antibiotics. Some examples of antibiotics, namely "amoxicillin", "super tetra" and "cefadroxil" were included in this question as what was conducted in Pakistan (Gillani et al., 2017). Three choices of answers which were "Yes", "No", and "Do Not Know" were provided to answer the first question. When answering "Yes", respondents were asked to answer three other questions. The second question was about the type of antibiotics ever used. Respondents may mention more than one type of antibiotics to answer this question. The third question was about whether the antibiotics were obtained without a prescription. Two choices of answers, which were "Yes" and "No", were provided to answer the third question. If they answered "Yes", the respondents did not need to continue answering the next question. Nevertheless, if they answered "No", the respondents were required to answer the last question. The last question was about the place where they purchased the antibiotics. The choices of answers for this fourth question included "Pharmacy", "Grocery Store", "Friend/Family", "Drug Store", "Doctor Practice", "Midwife Practice", "Health Care", "Supermarket", and "Mantri". Pre-testing of the questionnaire was conducted by recruiting 30 respondents before the actual survey to determine the face validity and the content validity of the questionnaire. Reliability test was also conducted at the pre-testing stage by using the test-retest method with a time gap of 14 days.

Antibiotics without prescription are defined as antibiotics obtained from a variety of sources without the use of legitimate prescriptions from authorized health personnel and without going through legal distribution channels. Self-dispensing medicine by selfemployed practices of health workers such as doctors, midwives, and mantri are included within these limits. Supermarkets, left over medicine at home, and health care without prescribing doctor services are included as the sources to obtain antibiotics without a prescription. The practice of using antibiotics without a doctor's prescription is also referred to as self-medication using antibiotics. The prevalence of consuming antibiotics without prescriptions or antibiotics self-medication was calculated from the number of respondents who claimed to purchase antibiotics without a prescription divided by the total of respondents who had used antibiotics. The data was recorded into Stata version 13 (Stata Corp., College Station, Texas, USA). The data were analyzed statistically using Chi-Square or Fisher's exact test with a 0.05 significance level to determine the correlation between socio-demographic factors as well as antibiotics use experience and prescription use to get the antibiotics. 
Table I. The Respondents' Socio-demographic Characteristics

\begin{tabular}{|c|c|c|c|c|c|c|c|c|}
\hline \multirow[t]{2}{*}{ Characteristics } & \multicolumn{3}{|c|}{$\begin{array}{l}\text { Ever consumed antibiotics? } \\
\qquad(\mathrm{N}=280)\end{array}$} & \multicolumn{5}{|c|}{$\begin{array}{c}\text { Purchasing antibiotics with } \\
\text { prescription? } \\
(\mathrm{N}=\mathbf{2 2 2})\end{array}$} \\
\hline & $\begin{array}{c}\text { Yes } \\
\mathrm{N}=222 \\
(\%)\end{array}$ & $\begin{array}{c}\text { No } \\
\mathrm{N}=58(\%)\end{array}$ & \multirow{2}{*}{$\begin{array}{r}\text { p Value } \\
0.82 \\
\end{array}$} & \multicolumn{2}{|c|}{$\begin{array}{c}\text { Yes } \\
\mathbf{N}=92 \\
(\%)\end{array}$} & \multicolumn{2}{|c|}{$\begin{array}{c}\text { No } \\
\mathrm{N}=130(\%)\end{array}$} & \multirow{2}{*}{$\begin{array}{r}\text { p Value } \\
0.81 \\
\end{array}$} \\
\hline Sex & & & & & & & & \\
\hline Male & (79) & $(21)$ & & 39 & $(42)$ & 53 & $(58)$ & \\
\hline Female & $130 \quad(80)$ & $(20)$ & & 53 & $(41)$ & 77 & $(59)$ & \\
\hline Semester & & & 0.12 & & & & & 0.90 \\
\hline 2 & $66 \quad(78)$ & $19 \quad(22)$ & & 26 & $(39)$ & 40 & $(61)$ & \\
\hline 4 & $62 \quad(85)$ & $11 \quad(15)$ & & 26 & (42) & 36 & $(58)$ & \\
\hline 6 & $48 \quad(71)$ & $20 \quad(29)$ & & 22 & $(46)$ & 26 & $(54)$ & \\
\hline 8 & $46 \quad(85)$ & $(15)$ & & 18 & $(39)$ & 28 & $(61)$ & \\
\hline Age & & & 0.25 & & & & & 0.67 \\
\hline$<20$ & $(80)$ & $14 \quad(20)$ & & 20 & $(36)$ & 35 & $(64)$ & \\
\hline $20-21$ & $(77)$ & $(23)$ & & 56 & $(43)$ & 73 & $(57)$ & \\
\hline$>21$ & $38 \quad(88)$ & $5 \quad(12)$ & & 16 & $(42)$ & 22 & $(58)$ & \\
\hline Residence & & & 0.01 & & & & & 0.43 \\
\hline $\begin{array}{ll}\begin{array}{l}\text { Boarding } \\
\text { house }\end{array} \\
\end{array}$ & $(76)$ & $(24)$ & & 62 & $(40)$ & 94 & $(60)$ & \\
\hline Home & $66 \quad(89)$ & $8 \quad(11)$ & & 30 & $(45)$ & 36 & $(55)$ & \\
\hline Place of Origin & & & 0.25 & & & & & 0.04 \\
\hline Urban & $(83)$ & (17) & & 47 & (49) & 48 & $(51)$ & \\
\hline Rural & $127 \quad(77)$ & $38 \quad(23)$ & & 45 & $(35)$ & 82 & $(65)$ & \\
\hline Insurance participants & & & 0.01 & & & & & 0.04 \\
\hline Yes & $86 \quad(88)$ & $12 \quad(12)$ & & 43 & $(50)$ & 43 & $(50)$ & \\
\hline No & $136 \quad(75)$ & $46 \quad(25)$ & & 49 & $(36)$ & 87 & $(64)$ & \\
\hline Monthly allowance (in & ands of Rupi & & 0.25 & & & & & 0.38 \\
\hline$<500$ & $86 \quad(83)$ & $(17)$ & & 37 & $(43)$ & 49 & $(57)$ & \\
\hline $500-1.000$ & $101 \quad(74)$ & $35 \quad(26)$ & & 40 & $(40)$ & 61 & $(60)$ & \\
\hline $1.000-1.500$ & $24 \quad(86)$ & $(14)$ & & 8 & $(33)$ & 16 & $(67)$ & \\
\hline$>1.500$ & $11 \quad(85)$ & $2 \quad(15)$ & & 7 & $(64)$ & 4 & $(36)$ & \\
\hline
\end{tabular}

\section{RESULTS AND DISCUSSION}

From the total of 324 non-health students participating in this study, 222 students $(68.5 \%)$ admit to having used antibiotics (Figure 1A). Among those who have used antibiotics, the type of antibiotics used is relatively limited. Nearly $90 \%$ of the students $(n=199)$ state that they had ever used only one type of antibiotics and none of the students consume more than two types of antibiotics. From the total of 245 mentions, amoxicillin (173 times, $70.6 \%$ ) is the most commonly mentioned antibiotics (Figure 1B). These results are consistent with the results of the study conducted among the students in Accra, Ghana (Donkor et al., 2012), Karachi, Pakistan (Shah et al., 2014), and Ahwaz, Iran (Sarahroodi et al., 2010) which also put 
amoxicillin on the first rank. The respondents of this study only mentioned five types of antibiotics, all of which are limited in the betalactam and tetracycline groups. Studies conducted by Shah et al. (2014) and Gillani et al. (2017) each mentions seven types of antibiotics used in self-medication by students. Sarahroodi et al. (2010) and Donkor et al. (2012) reported even more types of antibiotics, which are eight and 13 antibiotics types.

The prevalence of consuming antibiotics without prescription in non-health student respondents was $58.6 \%$ (Table I). This study is in line with the results of other studies showing that the prevalence of self-medication using antibiotics is still relatively high. One of the examples is from the study conducted on the students in Punjab, Pakistan which is $45 \%$ (Gillani et al., 2017) and in Accra, Ghana which is $70 \%$ (Donkor et al., 2012). Selfmedication practices using antibiotics without a doctor's prescription are not significantly different based on the sex $(\mathrm{p}=0.81)$, batch $(\mathrm{p}=0.90)$, age $(\mathrm{p}=0.67)$, residence $(\mathrm{p}=0.43)$ and the amount of allowance $(\mathrm{p}=0.38)$. However, self-medication practices using antibiotics are associated with the students' place of origin $(\mathrm{p}=0.04)$ and insurance membership $(\mathrm{p}=0.04)$ (Table I). Students who have an insurance are less likely to practice self-medication using antibiotics compared to those who do not have an insurance (50\% vs 64\%). This study is in line with the study conducted in Yogyakarta, Indonesia which states that the respondents who do not have an insurance are 1.5 times more likely to practice self-medication (Widayati et al., 2011). Participation in health insurance may decrease self-medication practices (Pagán et al., 2006), this is possible because insurance participants feel the need to take advantage of facilities covered by insurance and insurance participants feel entitled to better health services.

Table II. Sources to Purchase Antibiotics Without Prescription

\begin{tabular}{lr}
\hline Source of antibiotics & Amount of mention (\%) \\
\hline Pharmacy & $82(46.3)$ \\
\hline Grocery store & $23(12.9)$ \\
\hline Friend/family & $22(12.4)$ \\
\hline Drug store & $18(10.1)$ \\
\hline Doctor practice & $9(5.0)$ \\
\hline Midwife practice & $9(5.0)$ \\
\hline Health care & $6(3.3)$ \\
\hline Supermarket & $5(2.8)$ \\
\hline Mantri & $3(1.6)$ \\
\hline Total & $\mathbf{1 7 7}(\mathbf{1 0 0})$ \\
\hline
\end{tabular}
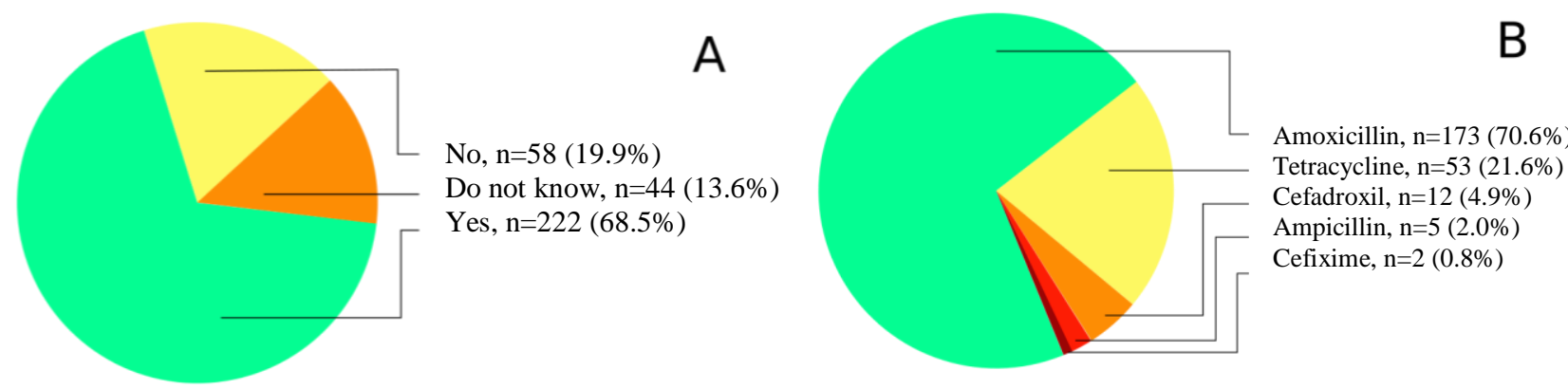

Figure 1. Distribution of the respondents' answers for the question "Have you ever consumed or use antibiotics?" (A) and distribution of antibiotics types among non-health students who ever consumed antibiotics whether for selfmedication or not (B). Every respondent may answer more than one type of antibiotics. 
In general, the use of antibiotics without a prescription is a convenient practice in many parts of the world and with a very diverse prevalence (Morgan et al., 2011, Ocan et al., 2015). Morgan et al. (2011) estimates the use of antibiotics without prescription in Asia at around 4-75\%. Ocan et al. (2015) estimates the same rate in the countries with low and middle income at the range of $38.8 \%$ (95\% CI: 29.5-48.1). Although it is a common thing to do, such practices are not in accordance with the applicable law. In Indonesia, antibiotics are classified as strong medicine that can only be obtained through prescription, except for some types of antibiotics for certain routes and in certain amounts which are included in the Pharmacy-Prescribed-Medicine (OWA) list (Health Minister of the Republic of Indonesia, 1986; Minister of Health of the Republic of Indonesia, 1993; President of the Republic of Indonesia, 2009; Directorate General of Pharmaceutical Services and Medical Devices, 1949). Prescription access is very important to suppress the rate of antibiotics resistance, although there is currently a debate about the need for non-prescription access for certain therapies, such as urinary tract infections (Llor, 2015).

Related to the source of purchasing antibiotics without prescription, out of 177 mentions (Table II), pharmacies $(\mathrm{n}=82$; $46.3 \%)$ are the most frequently mentioned source, followed by grocery stores $(n=23$; $13.0 \%)$ and friends/family $(n=22 ; 12.4 \%)$. No respondents mentioned any additional sources other than the ten kinds of outlets provided in the questionnaire. If compared to results of the previous studies, sources other than pharmacies are usually ranked in varying degrees or proportions. However, pharmacies tend to rank highest as reported in three systematic reviews (Morgan et al., 2011; Shaghaghi, 2014; Ocan et al., 2015). These results indicate that pharmacists in the community have an important role and a great opportunity to control the purchase of antibiotics without a prescription. It is important to note that in Indonesia, one of the most common sources of antibiotics without prescription is the roadside stalls, as reported in the study conducted in Yogyakarta (Widayati et al., 2011) and in Surabaya (Hadi et al., 2010).

There are some limitations in this study that include the sampling process which uses the convenient sampling technique and not using the random sampling technique. However, to minimize the limitations, the respondents were taken in a considerable amount and the number of respondents was proportioned in accordance to the total number of students in each non-health study programs.

\section{CONCLUSION}

The results of this study indicate that the use of antibiotics without prescription is still relatively high among non-health students and sales of antibiotics without prescription at pharmacies in Jember tend to be high. Therefore, the real actions from the government, relevant professional organizations, and educational institutions to conduct interventions are needed. Further research needs to be conducted to determine the factors that are associated with the high sales of antibiotics without prescription at the pharmacies.

\section{REFERENCES}

Aoyama, I., Koyama, S., and Hibino, H., 2012. Self-medication behaviors among Japanese consumers: sex, age, and SES differences and caregivers attitudes toward their children's health management. Asia Pacific Family Medicine, 11(1), 7.

Badan Penelitian dan Pengembangan Kesehatan, 2013. Riset Kesehatan Dasar 2013. Jakarta: Kementerian Kesehatan Republik Indonesia.

Bertoldi, A. D., Camargo, A. L., Silveira, M. P., Menezes, A. M., Assuncao, M. C., Goncalves, H., and Hallal, P. C., 2014. Self-medication among adolescents aged 18 years: the 1993 Pelotas (Brazil) birth cohort study. The Journal of Adolescent Health, 55(2), 175-81.

Clement, Y. N., 2009. Herbal self-medication at primary health care facilities in 
Trinidad. Journal of Alternative and Complementary Medicine, 15 (1), 6-7.

Directorate General of Pharmaceutical Services and Medical Devices, 1949. Undang-Undang (Ordonansi) Obat-Obat Keras, Staatblad No. 419.

Donkor, E. S., Tetteh-Quarcoo, P. B., Nartey, P., and Agyeman, I. O., 2012. Selfmedication practices with antibiotics among tertiary level students in Accra, Ghana: a cross-sectional study. International Journal of Environmental Research and Public Health, 9(10), 35193529.

Du, Y., and Knopf, H., 2009. Self-medication among children and adolescents in Germany: results of the National Health Survey for Children and Adolescents (KiGGS). British Journal of Clinical Pharmacology, 68 (4), 599-608.

Eticha, T., and Mesfin, K., 2014. Selfmedication practices in Mekelle, Ethiopia. PLoS One, 9 (5), e97464.

Gillani, A. H., Ji, W., Hussain, W., Imran, A., Chang, J., Yang, C., and Fang, Y., 2017. Antibiotic self-medication among nonmedical iniversity students in Punjab, Pakistan: a cross-sectional survey. International Journal of Environmental Research and Public Health, 14 (10).

Guinovart, M. C., Figueras, A., Llop, J. C., and Llor, C., 2015. Obtaining antibiotics without prescription in Spain in 2014: even easier now than 6 years ago. The Journal of Antimicrobial Chemotherapy, 70 (4), 1270-1271.

Hadi, U., van den Broek, P., Kolopaking, E. P., Zairina, N., Gardjito, W., Gyssens, I. C., and Amrin, S. G., 2010. Cross-sectional study of availability and pharmaceutical quality of antibiotics requested with or without prescription (over the counter) in Surabaya, Indonesia. BMC Infectious Diseases, 10.

Hassali, M. A., Shafie, A. A., Al-Qazaz, H., Tambyappa, J., Palaian, S., and Hariraj, V., 2011. Self-medication practices among adult population attending community pharmacies in Malaysia: an exploratory study. International Journal of Clinical Pharmacy, 33 (5), 794-799.

Health Minister of the Republic of Indonesia, 1986. Keputusan Menteri Kesehatan no 02396/A/SK/VIII/86 tentang tanda khusus obat keras daftar G. Jakarta: Menteri Kesehatan Republik Indonesia.

Jerez-Roig, J., Medeiros, L. F., Silva, V. A., Bezerra, C. L., Cavalcante, L. A., Piuvezam, G., and Souza, D. L., 2014. Prevalence of self-medication and associated factors in an elderly population: a systematic review. Drugs \& Aging, 31 (12), 883-896.

Khanra, S., and Sen, S., 2016. Chronic selfmedication with amlodipine for headache in a young adult with depression. International Journal of Green Pharmacy, 10 (3), 201-203.

Llor, C., 2015. Antibiotics without prescription: more cons than pros. British Medical Journal, 351, h4202.

Mehuys, E., Gevaert, P., Brusselle, G., Van Hees, T., Adriaens, E., Christiaens, T., Van Bortel, L., Van Tongelen, I., Remon, J. P., and Boussery, K., 2014. Selfmedication in persistent rhinitis: overuse of decongestants in half of the patients. The Journal of Allergy and Clinical Immunology in Practice, 2(3), 313-319.

Minister of Health of the Republic of Indonesia, 1993. Peraturan Menteri Kesehatan no 919/Menkes/Per/X/1993 tentang kriteria obat yang dapat diserahkan tanpa resep. Jakarta: Menteri Kesehatan Republik Indonesia.

Morgan, D. J., Okeke, I. N., Laxminarayan, R., Perencevich, E. N., and Weisenberg, S., 2011. Non-prescription antimicrobial use worldwide: a systematic review. The Lancet Infectious Diseases, 11(9), 692701.

Ocan, M., Obuku, E. A., Bwanga, F., Akena, D., Richard, S., Ogwal-Okeng, J., and Obua, C., 2015. Household antimicrobial self-medication: a systematic review and meta-analysis of the burden, risk factors and outcomes in developing countries. BMC Public Health, 15, 742. 
Olayemi, O. J., Olayinka, B. O., and Musa, A. I. 2010. Evaluation of antibiotic selfmedication pattern amongst undergraduate students of Ahmadu Bello University (main campus), Zaria. Research Journal of Applied Sciences Engineering and Technology, 2 (1), 3538.

President of the Republic of Indonesia, 2009. Peraturan Pemerintah Republik Indonesia no 51 Tahun 2009 tentang pekerjaan kefarmasian. Jakarta: Presiden Republik Indonesia.

Ruiz, M.E., 2010. Risks of self-medication practices. Current Drug Safety, 5 (4), 315 323.

Sarahroodi, S., Arzi, A., Sawalha, A. F., and Ashtarinezhad, A., 2010. Antibiotics selfmedication among Southern Iranian University students. International Journal of Pharmacology, 6 (1).

Selvaraj, K., Kumar, S. G., and Ramalingam, A., 2014. Prevalence of self-medication practices and its associated factors in Urban Puducherry, India. Perspectives in Clinical Research, 5 (1), 32-36.
Shaghaghi, A., Asadi, M., and Allahverdipour, H., 2014. Predictors of self-medication behavior: a systematic review. Iranian Journal of Public Health, 43 (2), 11.

Shah, S. J., Ahmad, H., Rehan, R. B., Najeeb, S., Mumtaz, M., Jilani, M. H., Rabbani, M. S., Alam, M. Z., Farooq, S. F., and Kadir, M. M., 2014. Self- medication with antibiotics among non-medical university students of Karachi: a cross-sectional study. BMC Pharmacology and Toxicology, 15 (74).

Skliros, E., Merkouris, P., Papazafiropoulou, A., Gikas, A., Matzouranis, G., Papafragos, C., Tsakanikas, I., Zarbala, I., Vasibosis, A., Stamataki, P., and Sotiropoulos, A., 2010. Self-medication with antibiotics in rural population in Greece: a cross-sectional multicenter study. BMC Family Practice, 11, 58.

Widayati, A., Suryawati, S., de Crespigny, C., and Hiller, J. E., 2011. Self medication with antibiotics in Yogyakarta City Indonesia: a cross sectional populationbased survey. BMC Research Notes, 4, 491. 